\title{
Effect Of Hepatitis C Virus On Duration Of Pregnancy And The Incidence Of Congenital Anomalies Of The Fetus
}

\author{
Abd El-Rahman Sayed Soliman ${ }^{1, *}$ M.B.B.CH, Abdelmoniem Mohamed Zakaria ${ }^{1}$ MD, \\ Bassem Ragab Abd El-Aziz ${ }^{1}$ MD
}

\section{*Corresponding Author: \\ Abd El-Rahman Sayed Soliman drabdelrahmansayed1993@gmail.com}

Received for publication July 29, 2021; Accepted September 16, 2021; Published online September 16, 2021.

CopyrightThe Authors published by Al-Azhar University, Faculty of Medicine, Cairo, Egypt. Users have the right to read, download, copy, distribute, print, search, or link to the full texts of articles under the following conditions: Creative Commons Attribution-Share Alike 4.0 International Public License (CC BY-SA 4.0).

doi: 10.21608 /aimj.2021.88169.1538

${ }^{1}$ Obstetrics and Gynecology Department, Faculty of Medicine Al-Azhar University Cairo, Egypt.

\begin{abstract}
Background: In spite of reports of raised rates of hypertensive problems, pre-mature births, and cholestasis, the influence of mother $\mathrm{HCV}$ infections on gestation complications and obstetrical outcomes hasn't been extensively defined.

Aim of the work: to examine the influence of Hepatitis C virus (HCV) infections during pregnancy on the duration of gestation as well as its possible effect on the incidence of congenital anomalies of the fetus.

Patients and methods: This work was a prospective observational casecontrol research had been done at Al-Hussein and Sayed Galal hospitals, Al-Azhar University during the period from December 2020 to June 2021. The study included ${ }^{12} 0 \mathrm{HCV}$ infected and $120 \mathrm{HCV}$ uninfected gravid females.

Results: Congenital anomalies in Group (A) show that 7(5.8\%) had congenital anomalies while in Group (B) $3(2.5 \%)$ had congenital anomalies. Nonsignificant changes have been found among studied groups. Significant changes have been found among studied groups as regard neonatal ICU admission where $\mathrm{P}=0.005$.

Conclusion: Gestations in females who are positive for anti-HCV have elevated rates of poor neonatal and obstetrical results, while correlations among neonatal and obstetrical results and HCV don't essentially mirror a causal association, HCV positivity can be a substitute indicator for raised risk of poor gestation outcome and the $\mathrm{HCV}$-positive gravid populations can need more clinical vigilance in this concern.
\end{abstract}

Keywords: Congenital anomalies, pregnant, $\mathrm{HCV}$ infection, neonatal $I C U$

\footnotetext{
Disclosure: The authors have no financial interest to declare in relation to the content of this article. The Article Processing Charge was paid for by the authors. Authorship: All authors have a substantial contribution to the article.
}

\section{INTRODUCTION}

About 185 million persons, or $2.8 \%$ of the universal populations, are presently or formerly disorderd with HCV. ${ }^{1}$ The valued 4.1 million individuals $(1.6 \%)$ in the United States with $\mathrm{HCV}^{2}$ are dwarfed by the 12 million $(14.7 \%)$ in Egypt. ${ }^{3}$

The prevalence rate of $\mathrm{HCV}$-infections in gravid females in the US was ranging between $1 \& 2.4 \%{ }^{4}$ and in Egypt between 15.7 \& 19\%. Regarding to centers for disorders control and prevention and the American college of obstetrics and gynecology strategies, worldwide screening of gravid females isn't endorsed in the US. ${ }^{5}$ In spite of having the highest global prevalence of worldwide screening of gravid females, it isn't showed in Egypt, and only risk-based screening is achieved

Vertical HCV transmission during gestation looks to be linked to the expectant mother's viremia rather than the birth route. When a woman's titer is less than $106 / \mathrm{mL}$ or she is negative, the virus doesn't seem to be transferred. ${ }^{6}$
The CDC indorses confirmations of a positive EIA with additional recombinant immunoblot assay (RIBA) or RT-PCR for HCV RNA. ${ }^{7}$

The relation between HCV during pregnancy and each of prematurity and congenital anomalies has not been established yet. ${ }^{6}$

\section{PATIENTS AND METHODS}

This work was undertaken at Al-Hussein and Sayed Galal hospitals at Al-Azhar University between December 2020 and June 2021 as a prospective observational case-control study. A total of 120 gravid females with $\mathrm{HCV}$ infection and 120 gravid females without $\mathrm{HCV}$ infection took part in the study.

A control group of 120 gravid females who are known to be infected with HCV will be recruited alongside a group of 120 gravid females who are not infected with $\mathrm{HCV}$. 
Cases that were included in the study were chosen based on the following criteria: Patients' age: 18-35 years, Singleton fetus and live fetus, pregnancy in the second or third trimester known to be infected with $\mathrm{HCV}$, patients' age: $18-35$ years:

Exclusion criteria of the cases: Patients' age: 18-35 years, Singleton fetus and live fetus, pregnancy in the second or third trimester known to be infected with HCV, patients' age: $18-35$ years

History of premature delivery, history of congenital malformed fetus in near family member, females previously infected and treated against $\mathrm{HCV}$, human immuno-deficiency virus, urinary tract infections, renal disorders, DM, pregnancy DM and chronic high blood pressure, any cardiovascular disorder, multiple gestations and history of congenital malformed fetus in the previous pregnancy.

Methods

Patients were subjected to:

Complete history taking: Personal history including name, age, marital state, address menstrual history: involving Menarche age, menstrual disturbances, dysmenorrhea, linked signs, obstetric history including parity and mode of delivery, present history: of chronic disorders and medication, past history of HTN, DM, family history of similar condition or diabetes, history of allergy to any medication and surgical history of operation, laparoscopic interference, treatment of hirsutism by Laser.

Examination: General examination: Evaluation of vital signs and measurement weight, height (BMI). Abdominal and local clinical examination: to assess fundal level and gestational age, scar of preceding surgeries, masses, tenderness or inflexibility and any abdominal or pelvic clinically detectable pathology. Bimanual pelvic examinations of both adenexa, and uterus for recognition of any irregularity of female genitalia

Investigations:

Laboratory: $\mathrm{CBC}$, coagulation profile, detection of albumin in urine sample by boiling or urine analysis, liver and kidney function tests. Virology: A blood sample will be withdrawn from all of the cases at the time of enrolment and to be sent for antibodies screening by ELISA or Rapid test and positive samples will be then examined for quantitative HCV RNA by PCR. Abdominal U/S: Abdominal ultrasound will be performed using abdominal U/S. All measurements will be performed by a single sonographer with the same machine. Fetal biometry, Amniotic Fluid Index (AFI) measurement, and anomaly scan to check for any congenital anomalies will be done. Once congenital anomalies are suspected, the patient is referred for anomaly scan by 4D US by fetal medicine specialist.

Outcome measures: Primary outcome: Pregnancy age at time of delivery and presence of congenital anomalies of the fetus. Secondary outcome: mode of delivery, apgar score at $1 \& 5 \mathrm{~min}$, neonatal delivery mass and ICU admittance.
Ethical approval has been attained from the IRB of faculty of medicine Al Azhar University. Informed verbal agreement was gotten from all involved cases. Secrecy and privacy have been respected in all levels of the work.

The data has been analyzed via IBM SPSS-20.0. software (Armonk, NY: IBM Corp) Qualitative data have been presented as numbers and percent. The Kolmogorov-Smirnov testing has been utilized to verify the normality of distribution Quantitative data have been presented as range (min and max), mean and standard deviation (SD). Significance level was set at the $5 \%$ level.

\section{RESULTS}

Patients were classified into 2 groups: Group (A): including 120 gravid females infected with HCV. Group (B): including 120 gravid females uninfected with HCV. A nonsignificant differences were found among groups regarding gravidity and abortion where $\mathrm{P}=0.097$. Table (1)

\begin{tabular}{|c|c|c|c|c|}
\hline Age & $\begin{array}{c}\text { Group (A) } \\
(\mathrm{n}=120)\end{array}$ & $\begin{array}{c}\text { Group (B) } \\
(\mathrm{n}=120)\end{array}$ & $\mathrm{U}$ & $\begin{array}{c}\mathrm{P} \\
\text { Value }\end{array}$ \\
\hline $\begin{array}{l}\text { Min.- } \\
\text { Max. }\end{array}$ & $21-37$ & $19-35$ & \multirow{2}{*}{7103.00} & \multirow{2}{*}{0.857} \\
\hline $\begin{array}{c}\text { Mean } \pm \\
\text { S.D }\end{array}$ & $26.80 \pm 5.157$ & $26.63 \pm 4.779$ & & \\
\hline \multicolumn{5}{|l|}{ Gravidity } \\
\hline $\begin{array}{l}\text { Min.- } \\
\text { Max. }\end{array}$ & $0-5$ & $0-5$ & \multirow{2}{*}{6296.50} & \multirow{2}{*}{0.088} \\
\hline $\begin{array}{l}\text { Mean } \pm \\
\text { S.D }\end{array}$ & $2.37 \pm 1.768$ & $2.74 \pm 1.683$ & & \\
\hline \multicolumn{5}{|l|}{ Parity } \\
\hline $\begin{array}{l}\text { Min.- } \\
\text { Max. }\end{array}$ & $0-5$ & $0-5$ & \multirow{2}{*}{6481.00} & \multirow{2}{*}{0.174} \\
\hline $\begin{array}{l}\text { Mean } \pm \\
\text { S.D }\end{array}$ & $2.14 \pm 1.579$ & $2.41 \pm 1.470$ & & \\
\hline \multicolumn{5}{|l|}{ Abortion } \\
\hline $\begin{array}{l}\text { Min.- } \\
\text { Max. }\end{array}$ & $0-3$ & $0-4$ & \multirow{2}{*}{6633.50} & \multirow{2}{*}{0.097} \\
\hline $\begin{array}{l}\text { Mean } \pm \\
\text { S.D }\end{array}$ & $0.23 \pm 0.667$ & $0.33 \pm 0.737$ & & \\
\hline
\end{tabular}

U: Mann-Whitney testing

$\mathrm{p}$ : $\mathrm{P}$ value for comparison among the groups

*: Statistically significant at $\mathrm{P}$-value $<0.05$

Table 1: Comparing among both groups as regard to patient's age (years) and patient's obstetric history

History of exposures to risk-factors in Group (A) show that about three quarter of the patients did not have a history of exposures to risk-factors $(77.5 \%)$ while in Group (B) the majority of the patients didn't had a history of exposure to risk-factors $(82.5 \%)$. A nonsignificant changes among both groups where $\mathrm{P}$ value $=0.317$. Table (2) 


\begin{tabular}{|c|c|c|c|c|c|}
\hline \multirow{2}{*}{$\begin{array}{c}\text { History of exposure } \\
\text { to risk-factors }\end{array}$} & \multicolumn{2}{|c|}{$\begin{array}{c}\text { Group (A) } \\
(\mathrm{n}=120)\end{array}$} & \multicolumn{2}{|c|}{$\begin{array}{c}\text { Group (B) } \\
(\mathrm{n}=120)\end{array}$} & \multirow{2}{*}{ P Value } \\
\cline { 2 - 5 } & No. & $\%$ & No. & $\%$ & \\
\hline No & 93 & 77.5 & 99 & 82.5 & \\
\hline Surgery & 10 & 8.3 & 5 & 4.2 & \multirow{2}{*}{0.186} \\
\hline Endoscopy & 7 & 5.8 & 9 & 7.5 & \\
\hline Dental treatment & 6 & 5.0 & 7 & 5.8 & \\
\hline Blood transfusion & 4 & 3.3 & 0 & 0 & \\
\hline Total & 120 & 100 & 120 & 100 & \\
\hline
\end{tabular}

$\mathrm{p}$ : P value for comparison among the groups *: significant at $\mathrm{P}$-value $<0.05$

Table 2: Comparing among the study groups as regard to patient's history of exposure to risk-factors

A statistically significant variances were found among groups regarding each of $\mathrm{Hb}$, platelet, AST, ALT, and INR where $\mathrm{P}<0.001$. Table (3)

\begin{tabular}{|c|c|c|c|c|}
\hline & $\begin{array}{c}\text { Group (A) } \\
(\mathrm{n}=120)\end{array}$ & $\begin{array}{c}\text { Group (B) } \\
(\mathrm{n}=120)\end{array}$ & $\mathrm{U}$ & P Value \\
\hline $\mathrm{Hb}$ & & & & \\
\hline $\begin{array}{l}\text { Min.- } \\
\text { Max. }\end{array}$ & $10.1-13.4$ & $11.1-14.1$ & \multirow{2}{*}{3967.50} & \multirow{2}{*}{$<0.001 *$} \\
\hline $\begin{array}{c}\text { Mean } \pm \\
\text { S.D }\end{array}$ & $11.79 \pm 0.899$ & $12.57 \pm 0.868$ & & \\
\hline \multicolumn{5}{|l|}{ Platelet } \\
\hline $\begin{array}{l}\text { Min.- } \\
\text { Max. }\end{array}$ & $195-234$ & $187-264$ & \multirow{2}{*}{5820.00} & \multirow{2}{*}{$0.010^{*}$} \\
\hline $\begin{array}{c}\text { Mean } \pm \\
\text { S.D }\end{array}$ & $213.78 \pm 11.121$ & $222.09 \pm 22.074$ & & \\
\hline \multicolumn{5}{|l|}{ AST } \\
\hline $\begin{array}{l}\text { Min.- } \\
\text { Max. }\end{array}$ & $35-81$ & $15-47$ & \multirow{2}{*}{130.00} & \multirow{2}{*}{$<0.001 *$} \\
\hline $\begin{array}{c}\text { Mean } \pm \\
\text { S.D }\end{array}$ & $57.92 \pm 13.083$ & $27.79 \pm 7.541$ & & \\
\hline \multicolumn{5}{|l|}{ ALT } \\
\hline $\begin{array}{l}\text { Min.- } \\
\text { Max. }\end{array}$ & $38-96$ & $25-52$ & \multirow{2}{*}{309.50} & \multirow{2}{*}{$<0.001^{*}$} \\
\hline $\begin{array}{c}\text { Mean } \pm \\
\text { S.D }\end{array}$ & $69.63 \pm 15.202$ & $37.98 \pm 8.476$ & & \\
\hline \multicolumn{5}{|l|}{ Creatinine } \\
\hline $\begin{array}{l}\text { Min.- } \\
\text { Max. }\end{array}$ & $0.6-1.4$ & $0.6-1.0$ & \multirow{2}{*}{7005.00} & \multirow{2}{*}{0.711} \\
\hline $\begin{array}{c}\text { Mean } \pm \\
\text { S.D }\end{array}$ & $0.82 \pm 0.163$ & $0.81 \pm 0.140$ & & \\
\hline \multicolumn{5}{|l|}{ Urea } \\
\hline $\begin{array}{l}\text { Min.- } \\
\text { Max. }\end{array}$ & $10.0-34.5$ & $10.0-20.0$ & \multirow{2}{*}{6299.00} & \multirow{2}{*}{0.094} \\
\hline $\begin{array}{c}\text { Mean } \pm \\
\text { S.D }\end{array}$ & $15.01 \pm 3.956$ & $15.29 \pm 2.800$ & & \\
\hline \multicolumn{5}{|l|}{ INR } \\
\hline $\begin{array}{l}\text { Min.- } \\
\text { Max. }\end{array}$ & $0.9-2.7$ & $0.6-1.3$ & \multirow{2}{*}{1503.00} & \multirow{2}{*}{$<0.001 *$} \\
\hline $\begin{array}{c}\text { Mean } \pm \\
\text { S.D }\end{array}$ & $1.74 \pm 0.549$ & $0.97 \pm 0.222$ & & \\
\hline
\end{tabular}

$\mathrm{U}$ : Mann-Whitney testing

$\mathrm{t}$ : T-Student testing

$\mathrm{p}$ : $\mathrm{P}$ value for comparison among the groups

*: significant at $\mathrm{P}$-value $<0.05$

Table 3: Comparing among two groups as regard to patient's laboratory investigations

Significant variances were found among both groups regarding gestational age at time of delivery where $\mathrm{P}<0.001$. Congenital anomalies in Group (A) show that $7(5.8 \%)$ had congenital anomalies while in Group (B) 3(2.5\%) had congenital anomalies. Nonsignificant variances were found among both groups where $\mathrm{P}=0.333$. Table (4)

\begin{tabular}{|c|c|c|c|c|c|}
\hline $\begin{array}{c}\text { Gestational } \\
\text { Age at } \\
\text { time of } \\
\text { delivery } \\
\end{array}$ & $\begin{array}{c}\text { Group (A) } \\
(n=120)\end{array}$ & $\begin{array}{c}\text { Group (B) } \\
(n=120)\end{array}$ & & $\mathrm{U}$ & P Value \\
\hline Min.-Max. & $30-40$ & $36-40$ & & \multirow[b]{2}{*}{3348.00} & \multirow[b]{2}{*}{$<0.001 *$} \\
\hline $\begin{array}{c}\text { Mean } \pm \\
\text { S.D }\end{array}$ & $34.74 \pm 3.392$ & \multicolumn{2}{|l|}{$37.93 \pm 1.538$} & & \\
\hline \multicolumn{6}{|l|}{$\begin{array}{c}\text { Congenital } \\
\text { anomalies }\end{array}$} \\
\hline No & 113 & 94.2 & 117 & 97.5 & \multirow{2}{*}{0.333} \\
\hline Yes & 7 & 5.8 & 3 & 2.5 & \\
\hline Total & 120 & 100 & 120 & 100 & \\
\hline
\end{tabular}

$\mathrm{U}$ : Mann-Whitney testing

$\mathrm{p}$ : $\mathrm{P}$ value for comparison among the groups

*: significant at $\mathrm{P}$-value $<0.05$

Table 4: Comparing among both groups as regard to patient's gestational age at time of delivery (weeks) and patient's congenital anomalies

Neonatal birth weight in Group (A) was ranged between 1734-3194 g with mean \pm S.D. $2497.42 \pm 445.112 \mathrm{~g}$ while in Group (B) was ranged between 1822-3815 g with mean \pm S.D. $2883.18 \pm 584.073$ g. Significant changes have been found among groups where $\mathrm{P}<0.001$. Neonatal ICU admission in Group (A) show that 22(18.3\%) of baby's were admitted to ICU while in Group (B) $7(5.8 \%)$ of baby's were admitted to ICU. A significant variances were found among both groups where $\mathrm{P}=0.005$. Table (5)

\begin{tabular}{|c|c|c|c|c|c|}
\hline $\begin{array}{c}\text { Neonatal } \\
\text { birth } \\
\text { weight }\end{array}$ & \multicolumn{2}{|c|}{$\begin{array}{c}\text { Group (A) } \\
(n=120)\end{array}$} & \multicolumn{2}{|c|}{$\begin{array}{c}\text { Group (B) } \\
(n=120)\end{array}$} & P Value \\
\hline $\begin{array}{l}\text { Min.- } \\
\text { Max. }\end{array}$ & \multicolumn{2}{|c|}{$1734-3194$} & \multicolumn{2}{|c|}{$1822-3815$} & \multirow{2}{*}{$<0.001^{*}$} \\
\hline $\begin{array}{c}\text { Mean } \pm \\
\text { S.D }\end{array}$ & \multicolumn{2}{|c|}{$2497.42 \pm 445.112$} & \multicolumn{2}{|c|}{$2883.18 \pm 584.073$} & \\
\hline \multicolumn{6}{|l|}{$\begin{array}{l}\text { Neonatal } \\
\text { ICU } \\
\text { admission }\end{array}$} \\
\hline No & 98 & 81.7 & 113 & 94.2 & \multirow{2}{*}{$0.005^{*}$} \\
\hline Yes & 22 & 18.3 & 7 & 5.8 & \\
\hline Total & 120 & 100 & 120 & 100 & \\
\hline
\end{tabular}

$\mathrm{p}$ : $\mathrm{P}$ value for comparison among the groups

*: significant at $\mathrm{P}$-value $<0.05$

Table 5: Comparison between two groups as regard to Neonatal birth weight and patient's neonatal ICU admission

\section{DISCUSSION}

In considering the correlations among mothers $\mathrm{HCV}$ infections and gestation outcome, the existence of simultaneous risk-factors of poor results, like poor perinatal care and simultaneous medication or alcohol usage, essential to be counted. ${ }^{8}$

So, in this work aim to examine the influence of $\mathrm{HCV}$ infections throughout gestation on the duration of gestation as well as its possible effect on the incidence of congenital anomalies of the fetus. 
On the other hand, in the present study, as regard abortion in Group (A) was ranging from 0 to 3 with mean \pm S.D. $0.23 \pm 0.667$ while in Group (B) was ranged between $0-4$ with mean \pm S.D. $0.33 \pm 0.737$. A nonsignificant change was found among groups regarding each of gravidity, parity and abortion.

In a study done by Abdulqawi et al., ${ }^{9}$ as regard Parity, it was found that parity>2 among 290 (25) in $\mathrm{HCV}$ positive women, and was 41 (49) in HCV negative women, A nonsignificant change was found among groups as regard parity with no differences as regard gravidity nor abortion.

In addition to above findings, we found that as regard history of exposures to risk-factors in Group (A) show that about three quarter of the patients did not have a history of exposures to risk0factors $(77.5 \%)$ while in Group (B) the mainstream of the cases didn't have a history of exposure to risk-factors $(82.5 \%)$. A nonsignificant change was found among groups.

While blood transfusions are currently considered a lesser significant risk-factor, it must be measured carefully, particularly in a republic with such an elevated prevalence of the disorder. Our findings are in accordance with those of Sangha et al., ${ }^{3}$ who revealed that a history of surgeries, blood transfusions, or injections to manage schistosomiasis elevated the risk of active infections with $\mathrm{HCV}$, nondependent of the other features.

Abdulqawi et al., ${ }^{9}$ reported that as regard history of exposure to risk-factors in $\mathrm{HCV}$ positive women showed that $15 \%$ had history of blood transfusion, 24 (29) had Major operation, 9 (0.8) had Major accidents, A nonsignificant change was found among groups as regard risk-factors except for blood transfusion.

In the study on our hands, it was revealed that significant changes have been found among groups as regard each of $\mathrm{Hb}$, platelets, ALT, AST, and INR, while there were non-significant differences as regard creatinine and urea.

Our results are supported by the study of McNicholas et al., ${ }^{10}$ which reported that Contributors with HCV infections had higher ALT, AST, and GGT levels at all-time points, and it was revealed that trimester altered the influence of $\mathrm{HCV}$, with $\mathrm{HCV}$-positive cases having higher transaminases in the $1^{\text {st }}$ (and $3^{\text {rd }}$ trimesters, and a leaning to significance for the $2^{\text {nd }}$ trimester.

Several researches propose that the fetuses of mothers with chronic HCV are at elevated risk for opposing newborn results. One research of Pergam et al., ${ }^{11}$ performed that baby of HCV mothers were more expected to be small for pregnancy age, need supported ventilations, be admitted to the ICU, or have lower births weights. Additional research of Connell et al., ${ }^{12}$ performed analogous implications, signifying that baby born to infected moms are at risk for lower delivery weights, pre-term delivery, and congenital irregularities, while confusing factors, like polysubstance abuse, weren't controlled for. A fresher research of Huang et al., ${ }^{13}$ established reduced intra-uterine embryonic growing of infants born to HCV mothers.

In a more recent study of Connell et al., ${ }^{12}$ utilized delivery certificate record of 1670369 gestations; it was revealed that cases with $\mathrm{HCV}$ were more expected to have infants delivered pre-term, with lower delivery weights and congenital irregularities. But that research has many limitations, especially, its retrospective design and the absence of associations with numerous variables, like the usage of tobacco, alcohol or drugs. Certainly, there is no clarification for pre-maturity and lower delivery weights in HCVnegative moms, while raised cytotoxicity of placental natural killer-T cells can be hypothesized possible. ${ }^{14}$

This can explained the findings of our study which stated that Congenital anomalies in Group (A) show that $7(5.8 \%)$ had congenital anomalies while in Group (B) 3(2.5\%) had congenital anomalies. Nonsignificant changes have been found among groups where $\mathrm{P}=0.333$.

Pergam et al. 11 found that babies born to HCVpositive moms were more expected to be lower delivery weights $(\mathrm{OR}, 2.17 ; 95$

5CI, 1.24, 3.80), small for gestational age (OR, 1.46; 95 percent CI, 1.00, 2.13), require assisted ventilation (OR, 2.37; 95 percent CI, 1.46, 3.85), and need NICU admittance (OR, 2.37; 95 percent CI, 1.46, 3.85). (OR, 2.91; 95 percent CI, 1.86, 4.55). HCVpositive moms who increased too much weights have elevated hazard of gestation diabetes (OR, 2.51; 95 percent CI, 1.04, 6.03). NICU hospitalization and the need for assisted ventilations still linked to $\mathrm{HCV}$ in the non-drug-using population.

This was in agreement with our findings, which demonstrated that neonatal birth weight in Group (A) was ranged between 1734-3194 g with mean \pm s.d. $2497.42 \pm 445.112 \mathrm{~g}$ while in Group (B) was ranged between 1822-3815 $\mathrm{g}$ with mean \pm s.d. $2883.18 \pm 584.073$ g. significant changes were found among groups $\mathrm{p}<0.001$.

In a separate study by Jabeen et al., ${ }^{15}$ had a number of 100 cases, and 85 of which were successful. Four pre-mature deliveries happened, one of which was a twin gestation, while 11 spontaneous mis-carriages happened. Following HCV infections, one miscarriage happened in the gestation. In the PCRpositive cases, there were two infant fatalities because of severe congenital defects. Only one (2.3 percent) of the children born to HCV-RNA positive moms tested positive for the virus.

The scarcity of data in neonates, combined with the rarity of many bad results, has made quantifying the risk of maternal HCV problematic. APGAR scores for children born to $\mathrm{HCV}$ exposed and unexposed women seem to be similar 17 in previous literature, which is consistent with our findings, where the APGAR score in Group (A) at 1 minute was ranged between 2-5 with mean S.D. 3.560 .562 and increased after 5 minutes to have a mean value of 7.690 .683 , while in Group (B) at 1 minute was ranged between 2-7 with mean S.D. 3.680.801 a Between groups, nonsignificant change was found. 
Also, Neonatal ICU admission in Group (A) showed that $22(18.3 \%)$ of babies were admitted to ICU, whereas $7(5.8 \%)$ of babies were admitted to ICU in Group (B). $\mathrm{P}=0.005$ indicated statistically significant differences across groups. Similar to our findings, Pergam et al., ${ }^{11}$ reported that maternal HCV remained strongly associated with NICU admission (OR, 2.80; 95\% CI, 1.83, 4.29) and with need for assisted ventilation (OR, 1.82; 95\% CI, 1.03, 3.22). Neonates born to $\mathrm{HCV}$-positive drug-using mothers did not have an increased risk of being LBW (OR, 1.19; 95\% CI, 0.74, 1.91), prematurity (OR, 1.03; 95\% CI, 0.66, 1.61), SGA (OR, 0.97; 95\% CI, 0.57, $1.64)$, or having a low apgar score (OR, $1.12 ; 95 \% \mathrm{CI}$ $0.60,2.08)$. There was a non-significant trend toward an association between HCV and neonatal jaundice.

A prospective study of Karampatou et al., ${ }^{8}$ was conducted on 145 gravid females from British Columbia who were HCV-positive detected a $3.4 \%$ rate of intrauterine fetal mortality, $17.9 \%$ rate of preterm delivery, $11.3 \%$ rate of small for gestation age, and $12.5 \%$ rate of low-delivery-weight infants, which were significantly high in comparison to rates in the general British Columbia population $(0.5 \%, 7 \%$, and $5 \%$, respectively).

\section{CONCLUSION}

While associations among obstetrical and neonatal outcomes and HCV mightn't always mirror a causal association, $\mathrm{HCV}$ positivity can be a substitute indicator for raised risk of poor gestation outcome, and the HCV-positive gravid women might need more clinical observance in this topic.

\section{REFERENCES}

1. Mohd Hanafiah, K, Groeger J, Flaxman A and Wiersma S. "Global epidemiology of hepatitis C virus infection: new estimates of age-specific antibody to HCV seroprevalence." Hepatology. 2013; 57 (4): 1333-42.

2. El-Kamary, SS, JR Serwint, A Joffe, M Santosham, and Duggan AK. "Prevalence of hepatitis C virus infection in urban children." J Pediatr. 2011; 143(1): 54-9.

3. Sangha J, Way A, El-Zanaty F, El-Sayed N. Riskfactors for hepatitis $\mathrm{C}$ infection in a national adult population: evidence from the 2008 Egypt DHS. XXVI IUSSP International Population Conference, [Session 57: Incorporating Biological Indicators in Demographic Studies], Marrakech, Morocco, September, 2009. Available from: http://iussp2009.princeton.edu/download. aspx?submissionId=93504. Accessed: May 31, 2010.

4. Armstrong GL, Wasley A, Simard E, McQuillan G, Kuhnert W and Alter M. "The prevalence of hepatitis C virus infection in the United States, 1999 through 2002." Annals of internal medicine. 2006; 144: 705-14.

5. ACOG. "Practice bulletin no. 159: Management of pre-term labor." Obstet Gynecol. 2016; 127(1): e2938.

6. El-Kamary SS, Hashem M, Saleh D and El-Ghazaly H. "Reliability of risk based screening for hepatitis c virus infection among gravid females in Egypt." $J$ infect. 2015; 70: 512-9.

7. CDC. Notes from the field: risk-factors for hepatitis $C$ virus infections among young adults, Massachusetts. 2011; 60 (42):1457-8.

8. Karampatou A, Han X, Kondili LA, Taliani G, Ciancio A, Morisco F, et al. PITER Framework Investigators; PITER Investigators. Premature ovarian senescence and a high miscarriage rate impair fertility in women with HCV. J Hepatol. 2018; 68:33-41. Erratum. In: J Hepatol 2018; 10.1016/j.jhep.2018.01.004.

9. Abdulqawi K, Rezk A, Metwally M, Ragih, I, AbdulHamid M, Shaheen A. Prospective Study of Prevalence and Risk-factors for Hepatitis $\mathrm{C}$ in Pregnant Egyptian Women and Its Transmission to Their Infants. Croatian medical journal. 2010; 51. 219-28. 10.3325/cmj.2010.51.219.

10. McNicholas L. F., Holbrook A. M., O'Grady, K. E., Jones, H. E., Coyle, M. G., et al. Effect of hepatitis C virus status on liver enzymes in opioid-dependent gravid females maintained on opioid-agonist medication. Addiction (Abingdon, England). 2012; 107 Suppl 1(0 1), 91-97.

11. Pergam S.A., Wang C.C., Gardella C.M., Sandison T.G., Phipps W.T., Hawes S.E. Pregnancy complications associated with hepatitis C: Data from a 2003-2005 Washington state birth cohort. Am. J. Obstet. Gynecol. 2008; 199:38.e1-38.e9.

12. Connell LE, Salihu HM, Salemi JL, August EM, Weldeselasse H, Mbah AK. Maternal hepatitis B and hepatitis C carrier status and perinatal outcomes. Liver Int. 2011; 31:1163-70.

13. Huang Q.T., Hang L.L., Zhong M., Gao Y.F., Luo M.L., Yu Y.H. Maternal HCV infection is associated with intrauterine fetal growth disturbance: A metaanalysis of observational studies. Medicine. 2016; 95.

14. Hurtado CW, Golden-Mason L, Brocato M, Krull M, Narkewicz MR, Rosen HR. Innate immune function in placenta and cord blood of hepatitis C-seropositive mother-infant dyads. PLoS One. 2010; 5: e12232.

15. Jabeen T, Cannon B, Hogan J, Crowley M, Devereux C, Fanning L, et al. Pregnancy and pregnancy outcome in hepatitis C type 1b. QJM. 2000; 93(9):597-601.

16. Jaffery T, Tariq N, Ayub R. Frequency of hepatitis C in pregnancy and pregnancy outcome. $J$ Coll Physicians Surg Pak. 2005; 15:716-9. 